\title{
Ayak bileği deformiteleri ve tedavi yöntemleri
}

\author{
Ankle deformities and treatment methods
}

\author{
Melih Civan ${ }^{1}$, Mehmet Çakmak ${ }^{2}$
}

\author{
${ }^{1}$ Gaziosmanpaşa Eğitim ve Araştırma Hastanesi, Ortopedi ve Travmatoloji Kliniği, İstanbul \\ ${ }^{2}$ İstanbul Üniversitesi, İstanbul Tıp Fakültesi, Ortopedi ve Travmatoloji Anabilim Dalı, (Emekli Öğretim Üyesi), İstanbul
}

\begin{abstract}
Ayak bileği, izole ya da kombine, tekli ya da çok planlı deformitelere ev sahipliği yapan ve yük taşıyan eklemlerden biridir. Bu deformiteler konjenital (doğumsal) ya da metabolik hastalıklardan, travma sonrası kaynama bozukluklarından, epifiz hasarlarından ya da dejeneratif eklem rahatsızlıklarından kaynaklanabilir. Geleneksel cerrahi yaklaşımlar tedavi için sıklıkla yetersizdir. Yük dağılımını bozan dizilim bozuklukları erken ayak bileği artrozuna sebep olabilir. Yük dağılımının fibulaya doğru kayması ile tibio-fibular ilişki ve mortis hattı bozulur. Eksternal fiksatör kullanılarak, distal tibianın akut ya da tedrici olarak yeniden diziliminin sağlanması tedavide değerli bir yöntemdir. Bununla birlikte eklem hattının yeniden oryante edilmesi ve distal tibianın diziliminin sağlanması için sistematik bir yaklaşım ve dikkatli bir deformite analizi gerekir. Bu makalede, distal tibia ve ayak bileği deformiteleri, etiyoloji, tedavi seçenekleri, sınıflaması ve cerrahi metodoloji ile birlikte sistematik bir sırada tartışılacaktır.
\end{abstract}

Anahtar sözcükler: ayak bileği; deformite; sınıflama; supramalleoler osteotomi
The ankle is one of the primary weight-bearing joints comprising isolated or combined, single or multiplanar deformities. These deformities can result from congenital or metabolic diseases, posttraumatic malunions, physical disturbances or degenerative joint diseases. Conventional surgical approaches are commonly inadequate for the treatment. Malalignment causing an altered load distribution leads to early ankle joint arthritis. The fibular shift of the ground reaction force widens the tibiofibular joint relation and mortise structure. The realignment of the distal tibia using acute or gradual correction with external fixation is a valuable procedure in the treatment. Therefore, a systematic approach and careful deformity analysis are required for the restoration of the joint orientation and distal tibia alignment. In this article, distal tibia and ankle deformities will be discussed in a systematic order with the etiologies, classifications, treatment options, and surgical methods.

Key words: ankle; deformity; classification; supramalleoler osteotomy

\section{ANATOMI, DiZiLIM VE TANIMLAMALAR}

Vücudun bir bölgesinde şekil ya da biçim bozukluğunun (deformite) tanımlanması için öncelikle normal anatomi ve dizilimin bilinmesi gerekir. Bu sayede patolojik anatomi daha niceliksel tanımlanır ve ortak bir dilde adlandırılır. Ayak ve ayak bileği bir bütün olarak vücudun her üç planında da hareket edebildiği için dizden daha karmaşık bir değerlendirme gerektirir. Ayak bileği değerlendirilirken, tibianın distal ucu, talus ve kalkaneusun fonksiyonel ve anatomik yapısı, sagittal ve koronal plan dizilimleri göz önünde bulundurulmalıdır. Normal dizilime sahip bir tibiada anatomik ve mekanik eksenler aynı kabul edilir. Bu eksen ayak bileğinin ortasından, bimalleoler orta hattan ya da tibio-talar eklem yüzeyi orta noktasından geçerek, tibia distal eklem yüzeyi ile $90^{\circ}$ 'lik bir açı yapar (a/mLDTA (anatomik/mekanik Lateral Distal Tibial Açı) $=90^{\circ}$ ). Talus orta noktası ile distal tibia eklem yüzeyi orta hattı arasında 1-2 mm'lik medial translasyon mevcuttur. Ayak bileğinde eklem oryantasyon çizgisi parallelliğinde, dizde olduğu gibi bir esneklik yoktur. Dolayısı ile talus kubbesi ile distal tibia eklem yüzeyi arasında açılanma normal anatomide görülmez (JLCA [joint line convergence angle] $=0^{\circ}$ ). Mekanik eksen, subtalar eklemden geçerken kalkaneus mekanik ekseninin 5-10 mm medialinde seyreder. Ayak bileği hareket açısı tek bir eksen üzerinde olsa da bu eksen koronal ya da sagittal planda yer almaz. Ayak bileği, talusun "kesik koni" (asimetrik makara) yapısından dolayı, oblik bir planda hareket eder. Kalkaneusun orta hattı ve vücut ağırlığının tabana iletildiği nokta, tibia ve talusun

- İletişim adresi: Op. Dr. Melih Civan, Karayolları Mahallesi, Osmanbey Caddesi, 621 Sokak, Gaziosmanpaşa / İstanbul

Tel: 0212 - 9453000 e-posta: melihcivan@gmail.com

- Geliș tarihi: 28 Kasım 2019 Kabul tarihi: 31 Ocak 2020 


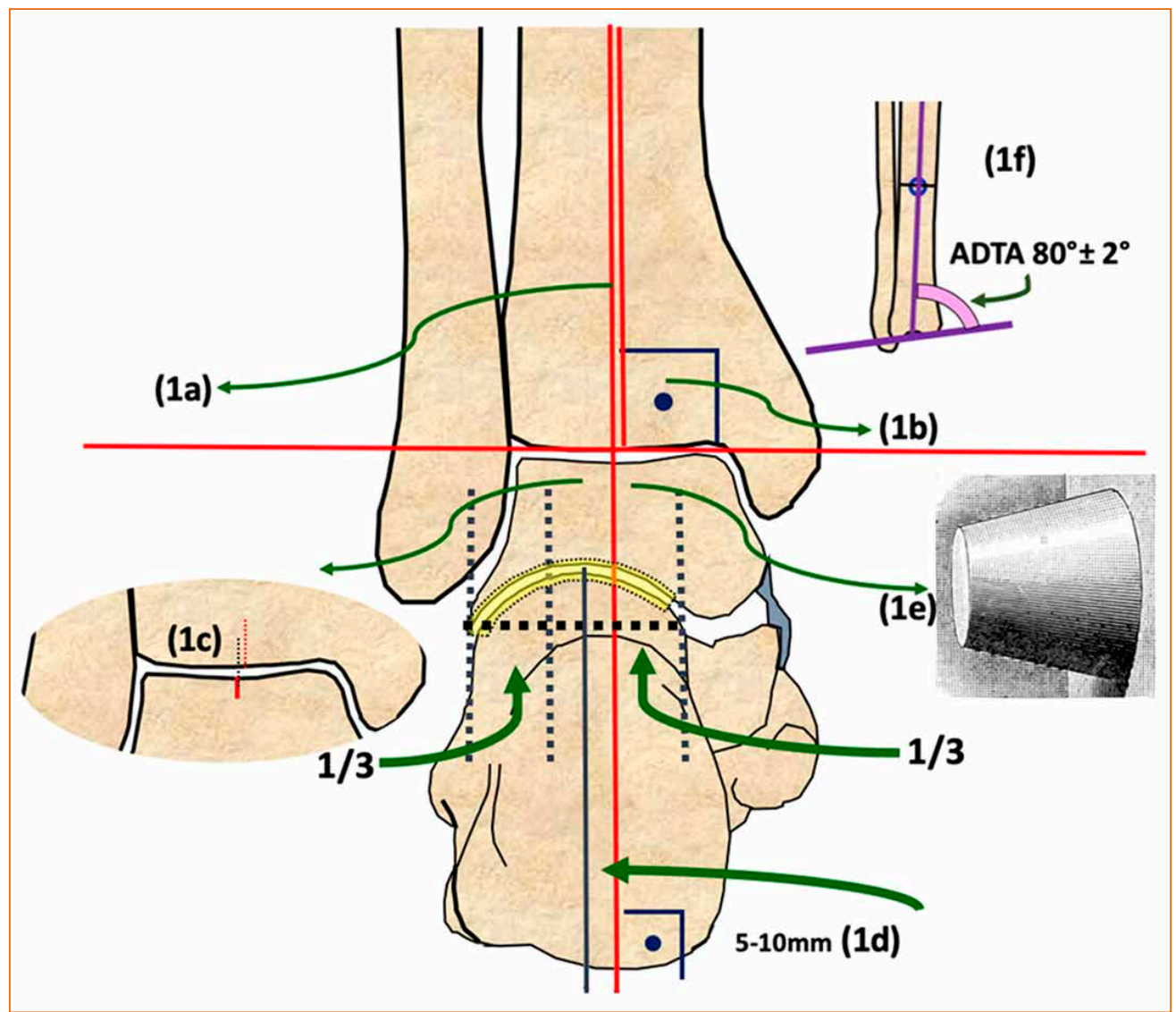

Şekil 1. Ayak bileğinde deformite analizinde kullanılan kılavuz çizgi ve noktaları. Tibiada anatomik ve mekanik eksenler aynı kabul edilir (1a). Bu eksen tibia distal eklem yüzeyi ile $90^{\circ}$ lik bir açı yapar (1b). Talus ve tibia eklem yüzeyi orta hatları arasında 1-2 mm'lik translasyon mevcuttur (1c). Mekanik eksen subtalar eklemden geçerken kalkaneus mekanik ekseninin 5-10 mm medialinde seyreder (1d). Ayak bileği, talusun kesik koni yapısından dolayı, oblik bir planda hareket eder (1e). Distal tibia eklem oryantasyon çizgisi sagittal planda yer ile $10^{\circ}$, tibia anatomik aksı ile $80^{\circ}$ 'lik bir açı yapar (1f). (Melih Civan, TOTBiD Dergisi 2020/2. sayı için çizmiştir.)

mekanik akslarından daha lateraldedir. Dolayısı ile tek ayak üzerine basıldığında yer reaksiyon kurveti ayak bileği lateralinden, diz medialinden ve asetabulum medial duvarının daha da medialinden geçerek $\mathrm{T} 10$ seviyesinde orta hatta ulaşır. Sagittal planda ise distal tibianın orta diyafizer mekanik ekseni ayak bileği rotasyon merkezi olarak da kabul edilen talusun lateral çıkıntısından geçer. Distal tibia eklem oryantasyon çizgisi sagittal planda yer ile 10 derecelik, tibia anatomik aksı ile 80 derecelik bir açı yapar (aADTA (anatomik Lateral Distal Tibial Açı) $\left.=80^{\circ}\right)$ (Şekil 1). ${ }^{[1]}$

Ayak bileğinde deformitelerin tanımlamasında deformite distalinin yönelimi ve hareketin olduğu plan göz önüne alınır. Sagittal plan deformitelerine örnek olarak plantar fleksiyonda nötral pozisyona gelmeyen ayak ve ayak bileği için "plantar fleksiyon deformitesi" ya da "ekinus deformitesi (pes equinus)" tabiri kullanılır. Dorsifleksiyondan nötral pozisyona gelmeyen ayakayak bileği için ise "dorsal fleksiyon deformitesi" ya da "kalkaneus deformitesi (pes kalkaneus)" tabiri kullanılır. Koronal planda arka ayak, inversiyon ve eversiyon hareketi, ön ve orta ayak ise supinasyon ve pronasyon hareketi yapar. Arka ayak varus ve valgus deformiteleri nötral pozisyona gelmeyen arka ayak için kullanılır (Şekil 2). Horizontal planda orta ve ön ayakta ise ayağın distal kısmının yönelimine göre adduksiyon veya abduksiyon deformiteleri olabilir. Pes kavus gibi sadece ayakta tanımlanan ya da pes ekinokavovarus gibi multiplanar deformiteler de diğer adlandırmalara örnek olarak verilebilir. Ayak bileği deformiteleri tek planda adlandırılırken normal anatomik oryantasyon açılarından sapma değerlerine göre de adlandırılabilir (Şekil 2). ${ }^{[2]}$ 

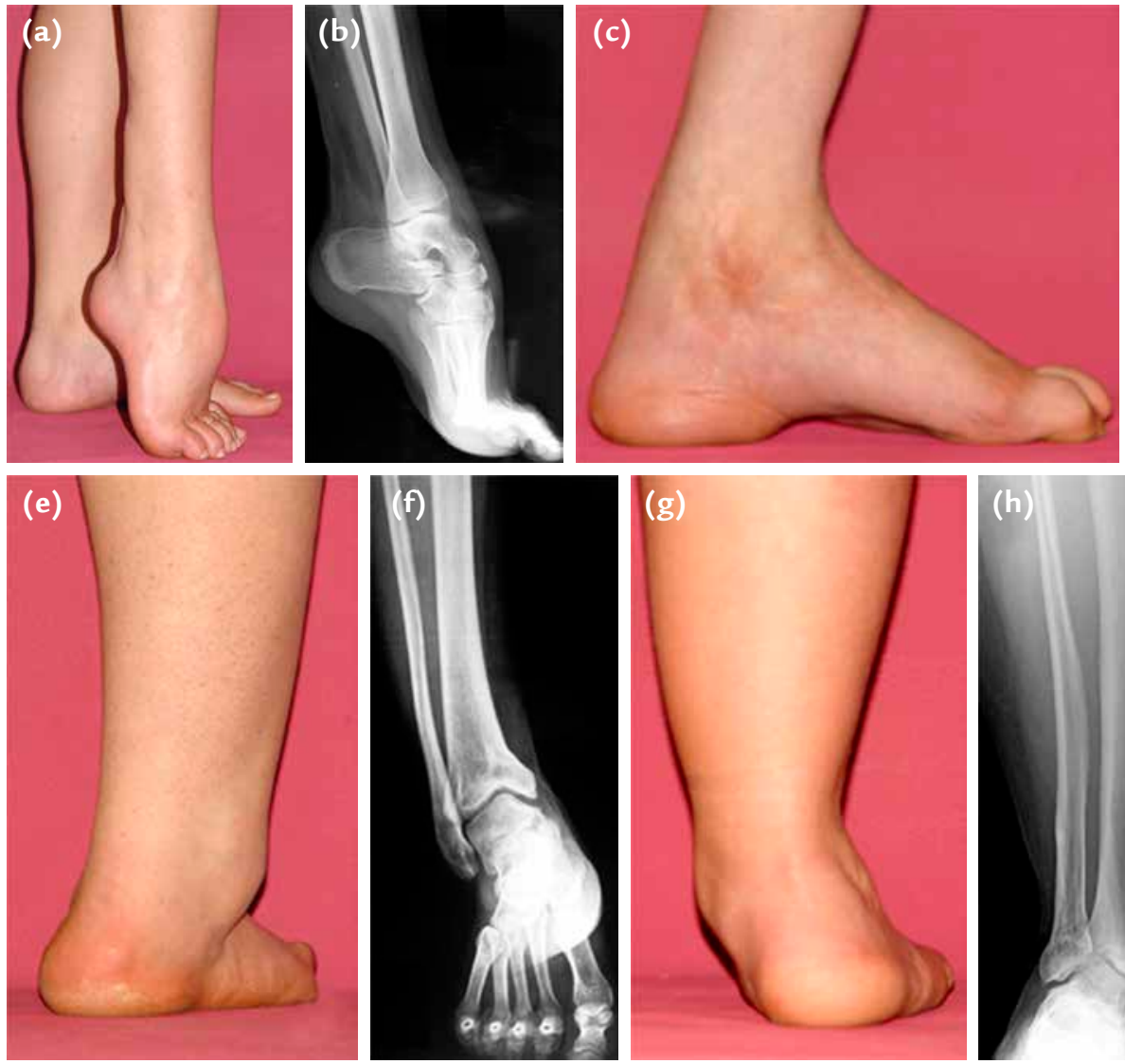

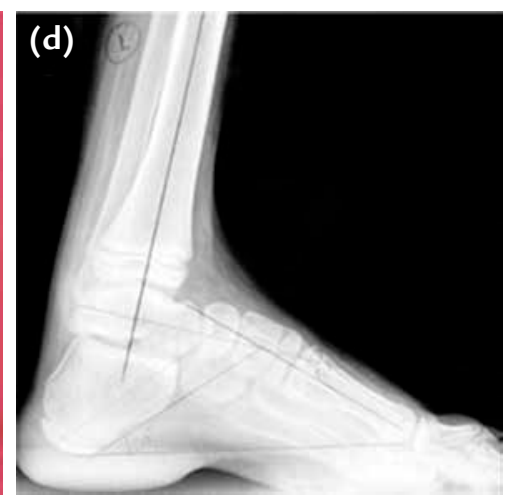

Şekil 2. a-h. Tek planda ayak bileği deformitelerine örnekler. Polyomiyelit sekeli iki hastanın pes ekinus $(a, b)$ ve pes kavus (c, d) deformiteleri ve iki farklı hastada travma sonrası ayak bileği varus (e, f) ve valgus $(\mathrm{g}, \mathrm{h})$ deformitelerinin klinik ve radyografik görüntüleri. (Istanbul Tıp Fakültesi, Ortopedi ve Travmatoloji Anabilim Dalı, ilizarov Arşivi.)
Türkçe literatürde ayak bileği deformiteleri ilizarov tedavi prensipleri göz önünde bulundurularak ilk kez Çakmak tarafından sınıflandırılmıştır. Bu sınıflandırmaya göre ayak bileği deformiteleri dört bölüme ayrılmaktadır (Tablo 1). ${ }^{[3]}$

\section{TiBiA ALT UÇ DEFORMiTELERi}

\section{Frontal Plan Deformiteleri}

Ayak bileği oryantasyonu tespit edilirken, tibia mekanik aksı ile tibiotalar eklem oryantasyon çizgisi arasındaki açı ölçülür. Bu açı "Lateral Distal Tibial Açı" (LDTA) olarak adlandırılır. Normalde ortalama $89^{\circ}$ olmakla birlikte $86-92^{\circ}$ aralığında normal sınırlarda kabul edilir (Şekil 3). Bazı durumlarda eklem hattında ve metafizodiyafizer bölgede birden fazla CORA (center of rotation of angulation) olabileceği unutulmamalıdır (multiapikal deformite). Bu deformiteler subtalar eklemden telafi edilmeye çalışılır. Normalde subtalar eklem arka ayağın $30^{\circ}$ inversiyon ve $15^{\circ}$ eversiyonuna izin vermektedir. Dolayısı ile varus deformitesi, subtalar eklemin eversiyonu ile $15^{\circ}$ ye kadar kompanse
Tablo 1. Ayak bileği deformiteleri sınıflaması ${ }^{[3]}$

I. Tibia Alt Uç Deformiteleri

a. Frontal Plan

Varus/Valgus (Epifizer/Metafizer)

b. Sagittal Plan

Prokurvatum/Rekurvatum (Epifizer/Metafizer)

c. Oblik Plan Deformiteleri

II. Yumuşak Doku Deformiteleri
a. Ekinus
b. Kalkaneus

III. Talus ve Kalkaneus Deformiteleri
a. Düz Çatılı Talus
b. Top Soket Tipi Ayak Bileği

IV. Çok Planlı Deformiteler
a. Fibular Hemimeli
b. Pes Ekinovarus / Ekinovalgus
c. Pes Kalkaneovarus / Kalkaneovalgus 


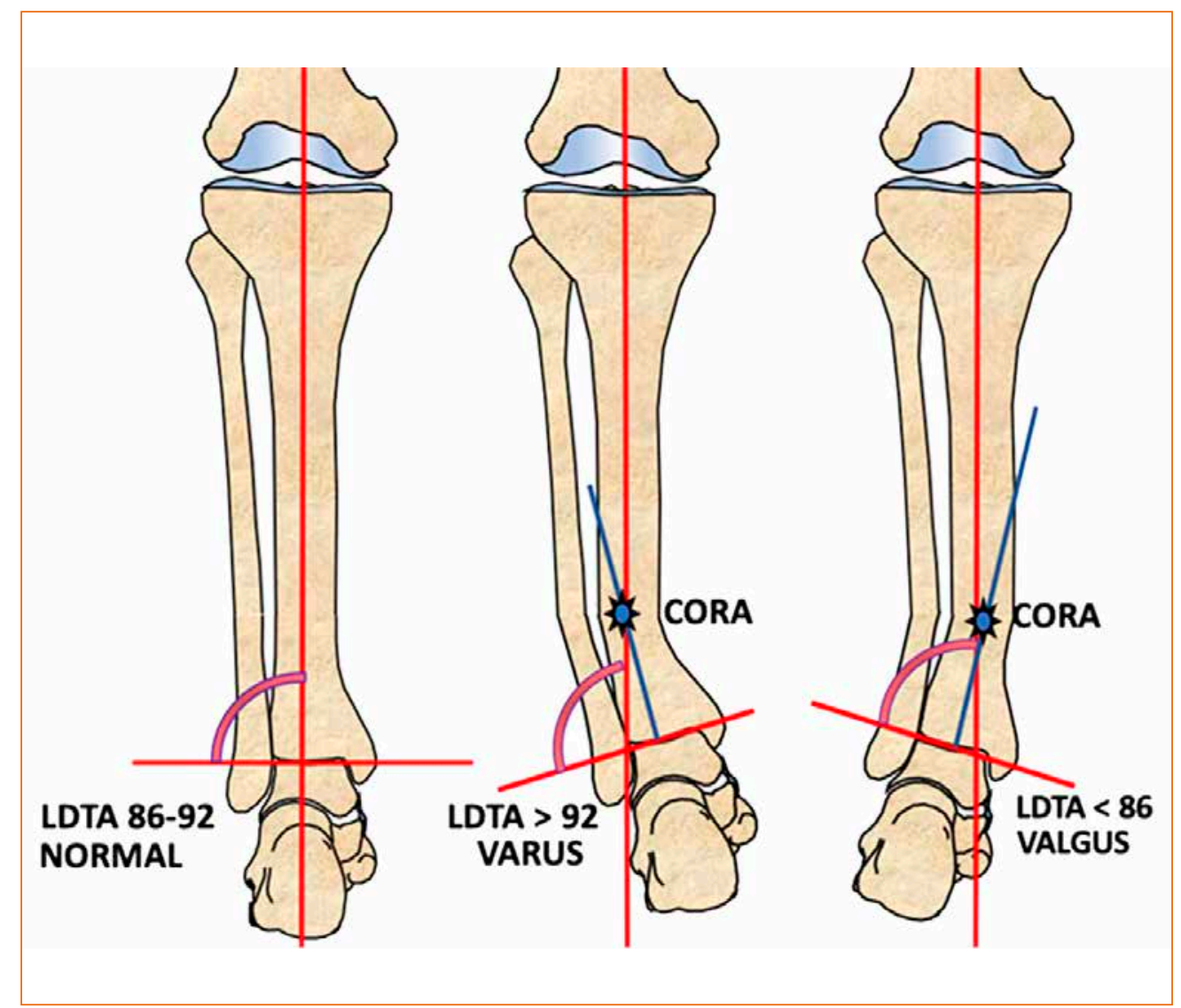

Şekil 3. Ayak bileği frontal plan deformitelerinin görselleştirilmesi. Ayak bileğinde frontal plan deformitelerinde subtalar eklemin telafi yeteneği göz önünde bulundurulmalıdır. Bu çizimde distal tibia diyafizinde tek CORA bulunmaktadır. Bu sebeple uniapikal bir ayak bileği deformitesi olarak adlandırılabilir. ${ }^{[3]}$

edilebilir. Valgus deformitesi ise subtalar eklemin inversiyonu ile $30^{\circ}$ ye kadar kompanse edilebilir. Dolayısı ile $30^{\circ}$ 'ye kadar olan valgus deformiteleri ve $15^{\circ}$ 'ye kadar olan varus deformiteleri sadece subtalar eklem ile kompanse edilebilir. Daha yüksek açılı deformitelerde ön ayak telafi mekanizmaları devreye girer ve vücut ayağı bir şekilde plantigrad bastırmaya çalışır.

Valgus deformitesinin $30^{\circ}$ ile kompanse edilmesi, klinik olarak ayak bileğinin daha az etkileneceği anlamına gelmez. Tam tersine ayak bileği valgus deformiteleri; uzun dönemde talusun ve yer reaksiyon kuvvetinin lateralize olması, ardından kuvvetin tibia yerine hareketli fibula üzerinden proksimale ulaşmasına sebep olur. Zamanla ayak bileğinde mortis hattı açılır ve eğer bu deformite erken yaşlarda meydana gelirse, distal epifiz hattının üçgen olarak şekillenmesi ile sonuçlanır. Bu son yıllarda "dinamik valgus deformitesi" olarak adlandırılan bir klinik tablodan ileri yaşlarda dejeneratif eklem hastalığına kadar değişen bir çeşitlilikte klinik bulgu verir. ${ }^{[4]}$ Varus deformitesi ise subtalar eklemde gelişen kontraktür sebebi ile ayak laterali üzerindeki bası yükünün artmasına sebep olur. Zamanla ayak lateralindeki yapıların ve tendonların bu maloryantasyondan zarar görmesi kaçınılmazdır.

Frontal planda hem varus hem de valgus deformiteleri, distal tibia metafiz ya da pilon kırıklarının hatalı kaynaması ya da sekeli olarak karşımıza çıkabilir. Çocukluk çağında distal tibia büyüme plağının bir kısmının ya da tamamının hasarlanması, yanık sekelleri ya da iskelet displazilerinde varus ya da valgus deformitesi görülebilir. Doğuştan ayak bileği medialinde yumuşak doku kontraktürü (PEV, pes ekinovarus), tibianın hipolazileri ya da aplazileri ayak bileği varus deformitesinin diğer sebepleridir. Ayak bileği valgusuna özel etiyolojilerin başında ise yazının ilerleyen bölümlerinde daha detaylı yer verilecek olan fibular bozukluklar yer alır. 
Son olarak Multipl Herediter Egzositozis (MHE ya da MO), Ollier Hastalığı ve nöromusküler bozuklukların uzun dönem sekelleri arasında daha çok valgus olmak üzere frontal plan deformiteleri sık görülmektedir. ${ }^{[5,6]}$

Deformite angulasyon merkezi (CORA)'nin eklem oryantasyon çizgisine yakın olması bir başka tanımlama ile "epifizer" olması daha çok genetik hastalıklar ve konjenital hastalıklara eşlik eden ayak bileği deformitelerinde görülmektedir. Bu tip deformitelerde ister varus ister valgus olsun sıklıkla CORA noktası distal tibia epifiz hattı seviyesindedir. Metafizer deformitelere örnek olarak travma sonrası iyileşme sekelleri, malunionlar hatta psödoartrozlar verilebilir. Bu tip edinsel deformitelerde CORA sıklıkla eklem hattından daha uzakta yer almaktadır. Deformite apeksi (CORA) proksimale doğru yer değiştirdikçe aLDTA'daki açılanma azalırken aMPTA (anatomik Medial Proksimal Tibial Açı)'nın etkilenme oranı artar.

\section{Frontal Planda Supramalleoler Osteotomiler}

Deformite tedavisinde prensip olarak ilk yapılması gereken kemiğin normal anatomiden ayrıldığı noktaları tespit etmektir. CORA olarak adlandırılan bu nokta metafizer deformitelerde genellikle kemik metafizodiyafizer bileşkesinde yer alırken, epifizer deformitelerde eklem hattına yakın hat içerisinde yer alabilir. Eklem hattına yakın CORA'larda düzeltme önceki bölümlerde bahsedilen osteotomi kurallarından "Kural 2" ile yapılır. Bu düzeltme seviyesinde translasyon yapılması ile mümkündür. Osteotomi hattı implantın izin verdiği en distal bölgede, metafiz iyileşmesinin diyafizden daha hızlı ve iyi olacağı gerçeği göz önünde bulundurularak yapılmalıdır. Kapalı ya da açık kama osteotomilerine eğer fibula da deformiteden etkilenmiş ise, fibular osteotomi eklenmelidir. Varustan valgusa düzeltmelerde medial translasyon, valgustan varusa düzeltmelerde ise lateral translasyon gereklidir. Bu translasyonun uygulanmadığı durumlarda "Z" tipi ayak deformiteleri ortaya çıkar. Varustan valgusa düzeltmelerde medial translasyon posterior tibial sinirin bası altında kalması ile sonuçlanabilir. Bu sebep ile özellikle akut düzeltmelerde profilaktik tarsal tünel gevşetmesi yapılabilir.

Osteotomi, "Kural 2"nin meydana getirdiği translasyona mecbur kalmamak için uygun cerrahi aletler varlığında dome osteotomisi yapılabilir. Bu osteotomi kubbe şeklinde olduğu için kubbenin merkezinden uzaklaşan Mose halkalarının tibiayı lateral ve medial korteksten kesen ve yeterli tespiti sağlayacak uzaklıktaki halka seçilerek yapılabilir. Dome ostetomisinde ne kadar uzak halka seçilirse fragman köşelerinin estetik kusur bırakma ihtimali artar. Ne kadar yakın halka seçilirse fragman tespiti o kadar zor olur. Bu sebeple tecrübe gerektiren zor bir ostoetomi tipidir. ${ }^{[7]}$
Eğer osteotomi için sirküler fiksatör ile tespit kullanılacaksa, ameliyattan en geç bir gün önce çerçevenin uygun şekilde planlanıp hazırlanarak steril edilmesi ameliyattaki anestezi süresini kısaltacak ve cerraha hem zaman hem de güven kazandıracaktır. Klasik ilizarov tipi sirküler fiksatör bu tip düzeltmelerde üç halkalı hazırlanır. Distal iki halka osteotomi hattının proksimalinde ve distalinde osteotomiyi kontrol edebilecek şekilde pozisyonlanır. Osteotominin proksimal komşu halkası proksimal diyafiz mekanik eksenine dik, distal komşu halka ise tibiotalar eklem oryantasyon çizgisine paralel olarak yerleştirilmelidir. Klasik sistemde varus ya da valgus düzeltmelerde menteşe tam CORA üzerine yerleştirilir. Motor ünite ise düzeltme yönüne açma kuvveti uygulayacak şekilde menteşeleri birleştiren hayali çizgiye ortasından dik olarak pozisyonlandırılmalıdır. Düzeltme miktarı hesaplanırken, deformitenin açısı, subtalar eklemin kompansasyon miktarı göz önünde bulundurularak, ayağın plantigrad basabildiği ilk açıya kadar düzeltme yapılır (Şekil 4). Düzeltme yapılırken açısal deformitelerin ne kadar düzeltileceğine ayak bileği kompansasyon mekanizmaları bölümünde değinilecektir. ${ }^{[8]}$

\section{Sagittal Plan Deformiteleri}

Sagittal planda tibia mekanik ekseni, distal tibia eklem oryantasyon (uyum) çizgisi ile $80^{\circ}$ 'lik açı yapar. Bu açının $82^{\circ}$ 'den büyük olması prokurvatum, $78^{\circ}$ 'den küçük olması rekurvatum deformitesi olarak adlandırılır. Ancak sağlıklı bir ayak bileğinin $20^{\circ}$ dorsifleksiyon, $50^{\circ}$ plantar fleksiyon hareket kabiliyeti bulunur. Dolayısı ile ayak bileğindeki prokurvatum ve rekurvatum deformiteleri bu oranlarda kompanse edilebilir (Şekil 5). Rekurvatum deformitelerinin prokurvatum deformitelerinden daha iyi tolere edilmesi tıpkı valgus deformitelerinde olduğu gibi daha iyi bir klinik ile sonuçlanacağı anlamına gelmez. Rekurvatum deformitesi ayak bileğinde yer reaksiyon kuvvetinin daha anteriordan geçmesine ve parmak ucunda yükselirken gastrosoleus kuvvet kolunun uzamasına sebep olur. Bu da yürümenin duruş (stance) fazına geçişini geciktirir. Ayrıca plantar fleksörlerin gücü de zaten plantar fleksiyonda duruş olduğu için normalden azdır. Bununla birlikte rekurvatum deformitesinde, tıpkı gelişimsel kalça displazisinde olduğu gibi talus anteriora sublukse olmaya meyillidir. Daha dik pozisyonlanan eklem oryantasyon çizgisi zaten $10^{\circ}$ 'lik yer ile açıya sahip olduğu için vertikal makaslama kuvvetleri eklem üzerine biner ve uzun dönemde daha hızlı bir dejeneratif sürece sebep olur. ${ }^{[9]}$

Prokurvatum deformitesinde talus anteriorunda impingement(sıkışma) sebebi ile sıklıkla merdiven çıkarken ya da yokuş yukarı yürürken ağrı meydana gelir. 

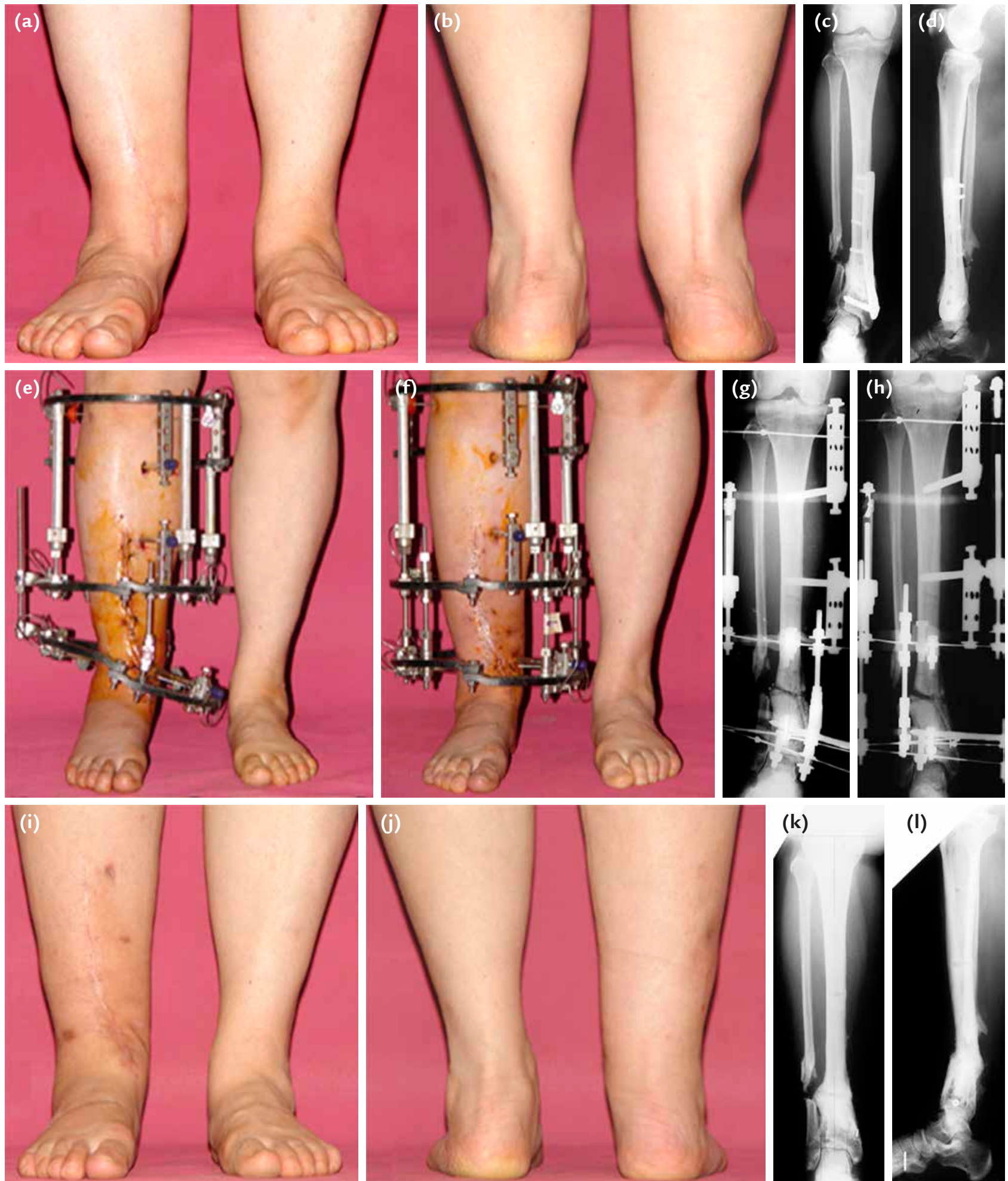

(k)

(I)

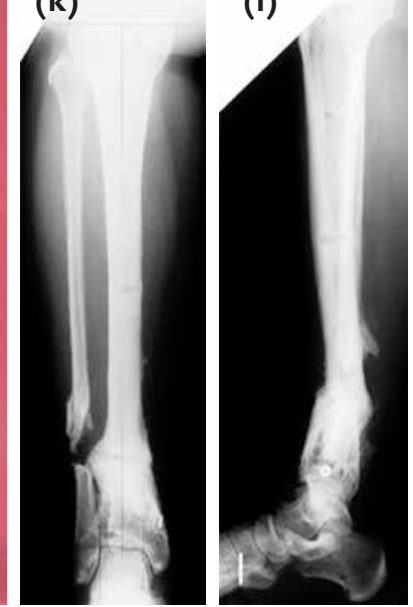

Şekil 4. a-I. Travma sonrası frontal plan ayak bileği valgus deformitesi. Ameliyat öncesi frontal plan klinik görünüm (a). Arka ayak valgus deformitesi klinik görünüm (b). Ameliyat öncesi ön-arka ve yan kruris grafisi (c, d). Tedrici düzeltme öncesi ve sonrası çerçeve konfigürasyonu $(e, f)$. Tedrici düzeltme öncesi ve sonrası osteotomi hattının gösterilmesi ( $g$, h). Ameliyat sonrası önden ve arkadan klinik görünüm: hasta tam yük altında basarken (i, j). Ameliyat sonrası mekanik ekseni düzelmiş tibianın ön-arka ve yan grafisi (k, I). (İstanbul Tıp Fakültesi, Ortopedi ve Travmatoloji Anabilim Dalı, İlizarov Arşivi.) 

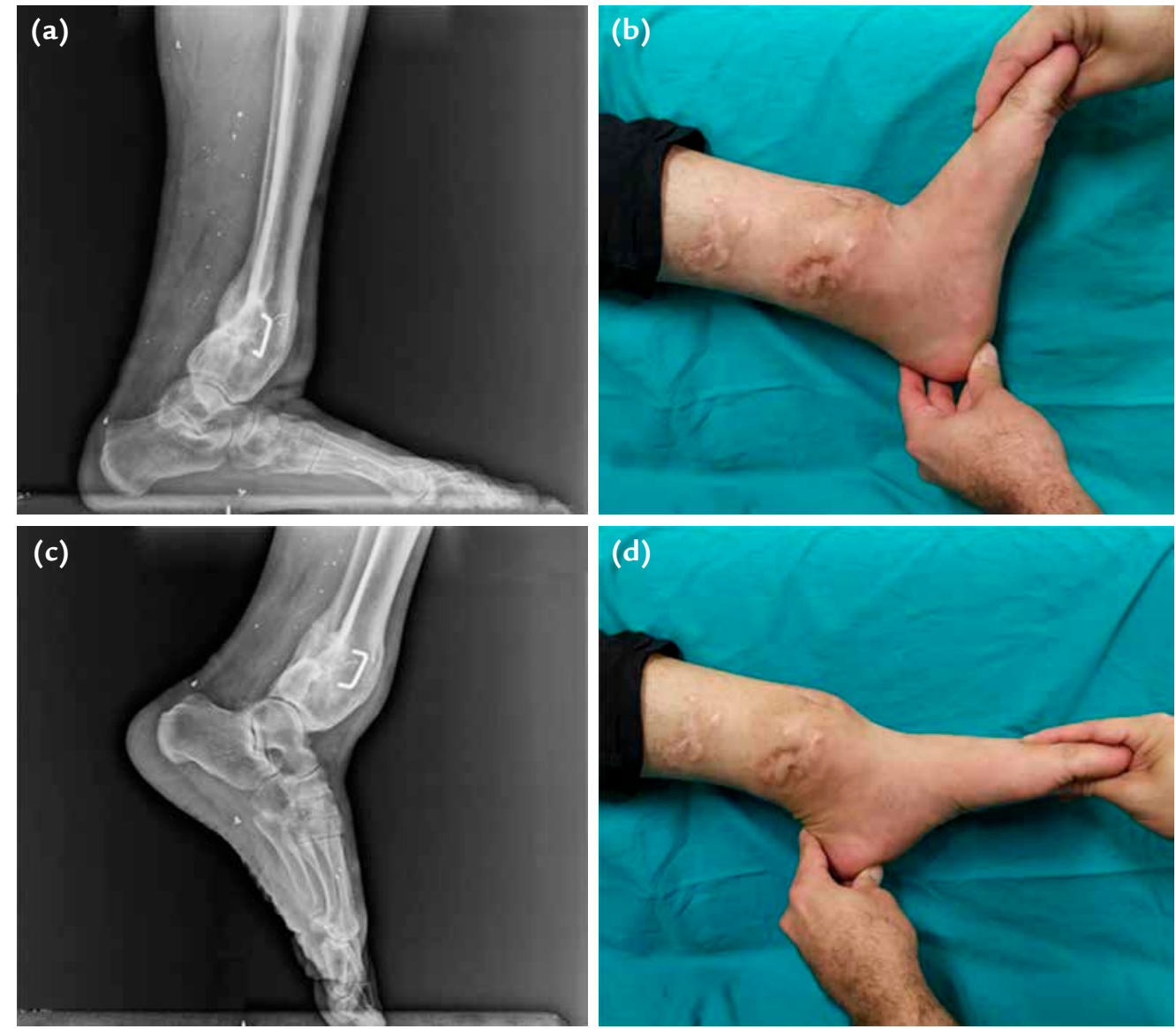

Şekil 5. a-d. Sagittal planda prokurvatum deformitesi ayak bileği dorsifleksiyon hareket açıklığı kadar tolere edilebilir. Ancak, bu tolerasyon klinik olarak ağrı ve sürekli anterior sıkışma bulguları ile sonuçlanır. Ayak bileği dışarıdan normal, ayak ise plantigrad basıyor olabilir. Ancak, deformite analizi dizilim ve yönelim kusurlarını ortaya çıkaracaktır. Distal tibiada travma sonrası malunion ve sagittal plan deformitesi olan hastanın, maksimum dorsifleksiyonda ve plantar fleksiyonda radyolojik (a, c) ve klinik görüntüleri $(b, d)$.

Sagittal planda ayak bileği artrodezi, malunionları ya da pes ekinovarusa eşlik edebilen flat top talusa sebep olan patolojilerde görülen ekinus deformitesinde ise, CORA ayak bileği eklem rotasyon merkezinde yer alır. Bu iki durum da sert bir ayak ve ayak bileği ile sonuçlanır. Bu deformitelerin tedavisinde de supramalleoler osteotomiler kullanılabilir.

\section{Sagittal Planda Supramalleoler Osteotomiler}

Sagittal plan deformitelerinin osteotomi ile düzeltilmesi esnasında rekurvatum düzeltilirken eğer translasyon uygulanmaz ise ayak posteriora kayar. Eğer prokurvatum deformitesi düzeltilirken translasyon uygulanmaz ise ayak anteriora doğru kayar. Anterior translasyon adım için gerekli zamanın artmasına ve sert bir ayak bileği ile sonuçlanan fonksiyonel yetersizliğe sebep olur. Kozmetik olarak da kötü bir görünüm ile sonuçlanır. İster rekurvatum olsun ister prokurvatum sebebi ile sagittal planda yapılan osteotomilerde kemik uçlarının yumuşak dokuya bası etkisi olacaktır. Bu sebeple yukarıda bahsedilen dome osteotomisi şart olmamakla birlikte tercih edilebilir (Şekil 6). ${ }^{[3]}$

\section{Oblik Plan Deformiteleri ve Oblik Plan Supramalleoler Osteotomiler}

Ayak bileğinde aynı zamanda hem sagittal hem de frontal planda deformite oluşabilir. Birbirleri ile ilişkili ve üst üste binmiş bu deformitelerin tedavisinde frontal ve sagittal plandaki prensipler göz önünde bulundurulur. Ancak deformitenin düzeltilmesi esnasında her iki planda da düzeltmeye izin verecek menteşe ve çerçeve konfigürasyonu gereklidir. 

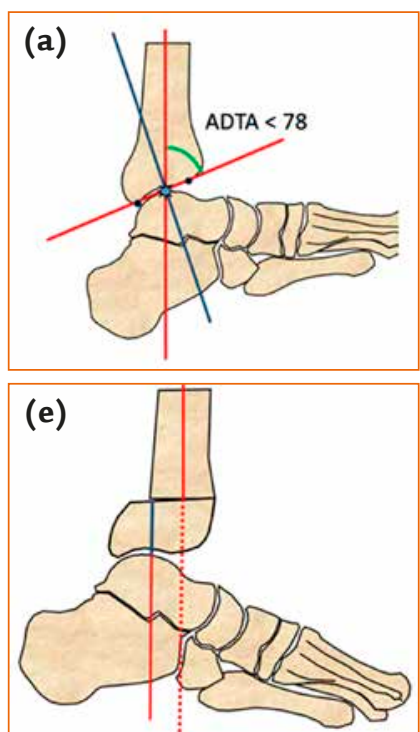
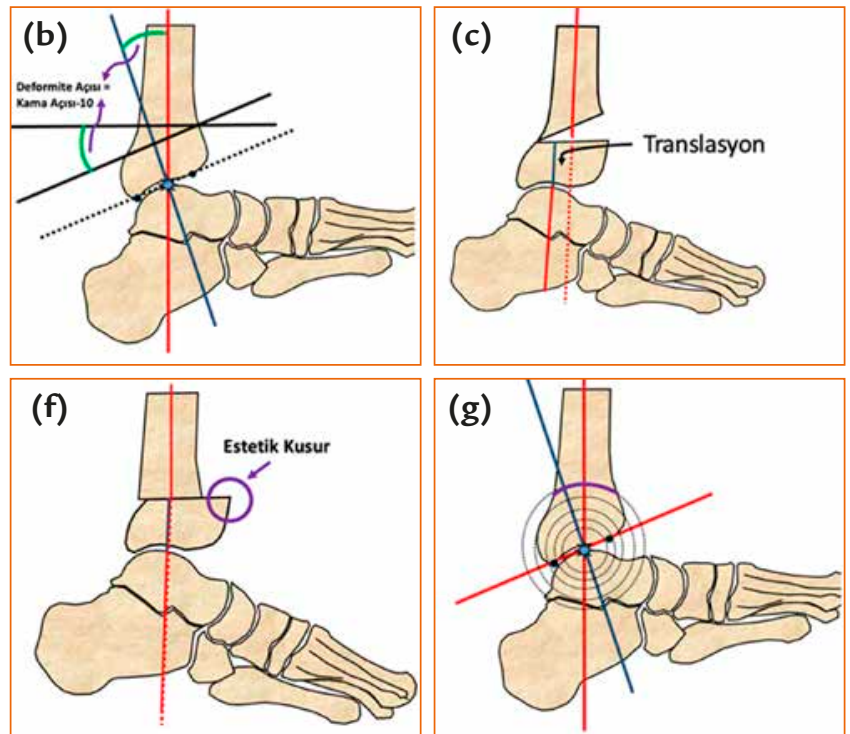
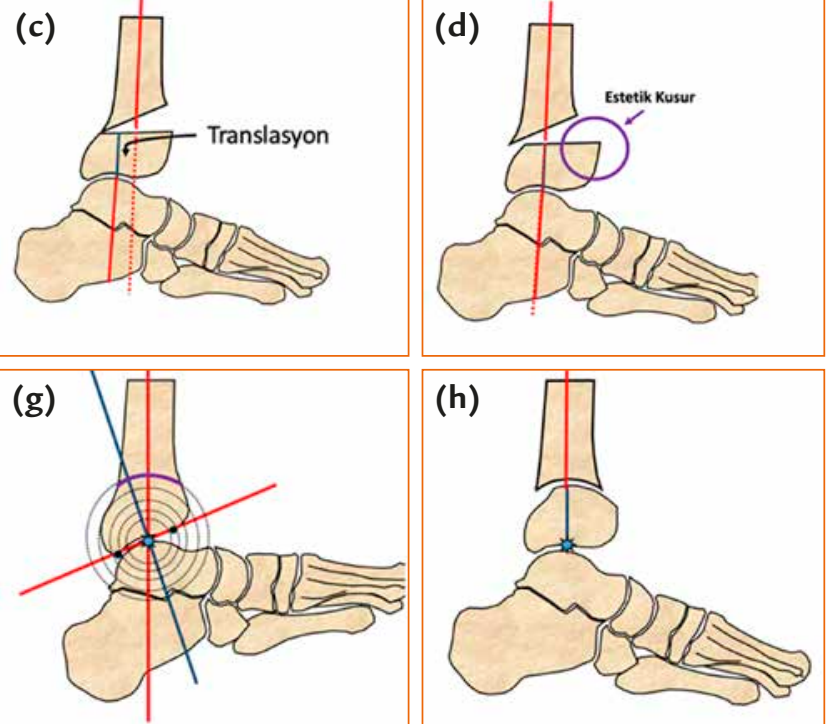

Şekil 6. a-h. ADTA $78^{\circ}$ 'den küçükse rekurvatum deformitesi mevcuttur. Ayak bileği rekurvatum deformitesinde CORA'nın bulunması (a). Açık kama osteotomisinde çıkarılacak kama açısının belirlenmesi (b). Açık kama osteotomisinde karşımıza çıkan translasyon sorunu (c). Bu sorunun düzeltilmesi esnasında ortaya çıkan estetik kusur (d). Kapalı kama osteotomisi esnasında karşımıza çıkan translasyon sorunu (e). Bu sorunun düzeltilmesi esansında ortaya çıkan estetik kusur (f). Tüm bu sorunlar olmasın diye planlanan dome (kubbe) osteotomisi (g). Dome osteotomisi ile deformitenin düzeltilmesi (h).

\section{Dikkat Edilmesi Gereken Telafi Mekanizmaları}

Ayak bileği, ön ayak ve subtalar eklem sebebi ile deformitelere telafi sağlayabilen bir anatomiye sahiptir. Bu telafi mekanizmaları tedavi esnasında bazı hataların meydana gelmesine yol açabilir. Örneğin ayak bileğinde $30^{\circ}$ valgus deformitesini, subtalar eklem tamamen kompanse edebilir. Ancak bu deformite düzeltildiğinde, uzun bir süreyi $30^{\circ}$ inversiyonda geçirmiş olan subtalar eklem çevresinde kontraktür oluşmuş ise ayak plantigrad yere basmayacaktır. Arka ayak bu kontraktür kadar varusta basmaya başlayacaktır. Böyle bir durumla karşılaşmamak için önceden çekilen stres grafileri ile kompansatuvar eklem açıklıklarının tayin edilmesi ve gerekirse ameliyat esnasında akut gevşetmeler ya da sonradan eklenen aparatlar ile komşu eklem distraksiyonu ya da tedrici gevşetmeler yapılabilir. Bir başka alternatif olarak yukarıda bahsedildiği gibi, kontraktür miktarı düzeltme miktarından düşülerek ayak plantigrad bastığında tedavi sonlandırılabilir. Sagittal planda ise ayak bileği oryantasyon hattının mümkün olan en fizyolojik sınırlara ulaştırılması hedeflenmelidir. Bu amaçla aşil tendonu gevşetme/uzatma ya da daha derin dokuda ayak bileği posterior kapsül/fasya gevşetme ameliyatları tedaviye eklenmelidir.

Ayak bileği deformitelerinin tedavisinde, diz ekleminin de durumu ve biyomekaniğe katkısı özellikle spastik ya da nöromusküler hastalıklarda hayati önem taşır.
Dizin hiperekstansiyon deformitesi, ayak ekinusu ile kompanse edilirken, diz fleksiyon kontraktürü, kalkaneal ayak deformiteleri ile kompanse edilir. Fikse fleksiyon deformitesi bulunan bir hastada kalkaneal deformitelerin düzeltilmesi ikinci aşamaya bırakılmalıdır.

Ayak bileği aynı zamanda özellikle çocukluk çağında başlayan frontal plan diz deformitelerinden de etkilenir. Örneğin dizde valgus deformitesi olan bir alt ekstremitede subtalar inversiyon ile zaman içinde yapılan kompansasyon, bu deformitenin zaman içinde kontraktüre dönüşmesi ile tedavide bir engel oluşturur. Kompansasyon, subtalar eklemi de aşarak, büyüme plağında remodelasyon ile daha kalıcı hale gelebilir. Bu durumda ayak bileği deformiteleri diz deformiteleri ile birlikte ya da yakın zaman aralıkları ile düzeltilmelidir. ${ }^{[2]}$

\section{AYAK BILEĞi ÇEVRESI KONTRAKTÜR, ARTROZ VE TEDAVILERI}

Ayak bileği çevresi kontraktürleri, bu kontraktürlere eşlik eden deformiteler ve ayak bileği ekleminde görülen orta dereceli osteoartrit, ilizarov tipi sirküler fiksatörler yardımı ile tedavi edilebilir. Ayak bileği deformitelerinin kemik ve yumuşak doku bileşenleri eklem oryantasyon çizgisi ve deformite analizi ile ayırılabilir. Örnek olarak ayak bileği ekinus kontraktürü, ayak bileği oryantasyon hattı sagittal planda prokurvatumda 
ise, flat top talus varsa ya da kavus ile birlikte ise bir kemiksel deformite içerir. Eklem oryantasyon hattı normal sınırlarda olduğunda, ayak kavusu olamadığında ve talokalkaneal anatominin normal olması durumunda izole ekinus kontraktüründen bahsedilebilir.

Ayak bileği kontraktürleri ekstra-artiküler, intra-artiküler ya da kombine deformiteler olarak da üçe ayrılabilir. Ekstra-artiküler kontraktürler aşil tendonu ve gastroknemius-soleus kompleksi ile ilişkili olabildiği gibi, tibialis posterior, fleksör digitorum longus ve fleksör hallusis longus kasları ile ilişkili de olabilir. Silfverskiold testinde diz fleksiyonda iken de kontraktür devam ediyor ise ya soleus kası kontraktürü ya da intra-artiküler patolojilere sekonder bileşenler mevcuttur. Konjenital olguların sıklıkla kapsüler ya da fasyal komponentleri vardır. Sadece aşil kontraktüründe perkütan aşil gevşetme yeterli iken, fasyal ya da kapsüler komponenti olan olgularda açık Aşil tendon uzatma ve akut ya da tedrici gevşetme eklenmelidir. Bu bahsi geçen ek gevşetmeler, posterior kapsülotomi, anterior osteofitlerin temizlenmesi ve sıkışmanın (impingement) önlenmesi, posterior derin fasyanın gevşetilmesi ve intra-artiküler yapışıklıkların temizlenmesi şeklindedir. Tedrici gevşetmeler ise daha önceden çoklu operasyonlar geçirmiş olan, rijid ve daha ileri ekinus kontraktürlerinde yapilır. ${ }^{[1-3]}$

\section{Ekinus Deformitesi}

Plantar fleksiyonun nötralden düzeltilmeyen kısmına ekinus deformitesi adı verilir. Ekinus deformitesi osseöz ya da musküler olabilir. Gerçek ekinus deformitesi ön ayaktan değil arka ayaktan meydana gelir. Dolayısı ile deformiteye talus ve kalkaneus da katılır. Ancak sadece ön ve orta ayağın kavus deformitesine sekonder ayak bileği yalancı ekinus (pseudoekinus) deformitesi de görülebilir. Bu tip durumlarda sagittal planda distal tibia, subtalar eklem ve kalkaneus normal anatomide görülür. Ekinus deformitesi, miyelodisplastik hastalıklarda, nöral tüp defektlerinde, poliyomyelitin total paralitik ya da dorsal zayıf kas gücü ile seyreden formlarında, serebrovasküler hastalıklar sonucu alt ekstremite kas dengesizliği gelişen hastalarda, serebral palside, alt ekstremite uzunluk eşitsizliklerinde, ihmal edilmiş düşük ayak durumunda, tibia uzatma ya da tibia segment kaydırma ameliyatlarının bir komplikasyonu olarak, kruriste yapılan her türlü doku transfiksasyonunda, hemofili hastalarında eklem içi ve kas içi kanamalar sonucunda ve ekinizmde yapılan alçı ve atel tedavisi sonrasında iyatrojenik olarak görülebilir. ${ }^{[10]}$

Ekinus deformitesinde etkilenen kas grubu Silfverskiold testi kullanılarak ayırt edilir. Ancak gastroknemiusun (GK) gevşek olup soleusun (S) izole kontrakte olduğu durum Silfverskiold ile ayırt edilemez. Pozitif test için GK gevşetme, negatif testte ise aşil tendon uzatma $(G K+S)$ ameliyatları tedavinin temelini oluşturur. Paley ve ark. tarihsel olarak yapılmış tüm gevşetme ameliyatlarını beş topografik bölgeye göre ayırmışlardır. En proksimalde Silfverskiold gevşetmesi yapılabilen beşinci bölge bulunur. Hemen distalindeki dördüncü bölge, GK ve $S$ kaslarının en kalın olduğu bölgedir. Bu bölgede yapılan gevşetmeye örnek olarak, daha çok serebral palsi hastalarında uygulanan Baumann gevşetmesi örnek verilebilir. GK kasının tendona döndüğü seviyeyi temsil eden üçüncü bölgede Strayer metodu, GK ve S'un birleştiği ikinci bölgede ise Vulpius ve Baker metodu kullanılarak gevşetme yapılabilir. Aşil tendonunu barındıran birinci bölgede ise perkütan, $Z$ şeklinde, açı $Z$, perkütan üçlü metodları ile uzatma yapılabilir. ${ }^{[11]}$

Ayak bileği ekinizm deformiteleri Türkçe literatürde açısal dereceye göre de sınıflandırılmıştır. Çakmak sınıflamasına göre 0-20 derece arasındaki ekinizm deformiteleri, kemik komponent yoksa yalnızca germe ve alçılama metodları ile tedavi edilebilen hafif ekinizm deformiteleridir. Yirmi ila kırk derece arasındaki orta dereceli ekinizm deformiteleri, yine osseöz patolojilerin eşlik etmediği durumlarda yukarıda bahsedilen yumuşak doku gevşetmeleri ile tedavi edilir. Kırk derecenin üzerindeki ekinizm deformitelerine kemik deformiteleri de eşlik eder. Sıkıkla ön ayak kavusu katkıda bulunan en önemli deformitedir. Bu tip ağır deformitelerde ön ayağı da içine alan klasik illizarov çerçeveleri kurulur. Klasik ilizarov çerçevesi, ekinus deformitesine eşlik eden kısalığın tedavisinde de başarı ile kullanılabilir. ${ }^{[3]}$

\section{Kalkaneus Deformitesi}

Kalkaneal deformiteleri konjenital kalkaneovalgus, edinsel pes kalkaneus ve pes kavus olarak üç şekilde görülür. Edinsel pes kalkaneus, daha çok ayak dorsifleksörleri ile plantar fleksörlerinin güç dengesinin bozulduğu nörolojik hastalıklarda görülen dinamik bir deformitedir. İzole kalkaneus deformitesi nadirdir. Valgus ya da varus deformitesi ile birlikte görülür. Konjenital kalkaneovalgus yenidoğanın bir intrauterin deformitesidir. Spontan ya da germe egzersizleri ile düzelir. Vertikal talustan mutlaka ayırt edilmelidir edilmelidir. Pes kavus posterior ise, kalkaneus deformitesine rağmen ön ayağın kavus sebebi ile yere basabildiği durumdur. Bu durum tibia alt uç deformitelerine ya da fibular hemimeliye kompansatuar olarak, rijid(sert) ayaklarda karşımıza çıkar. Paralitik ayaklarda görülen pes kalkaneusta tendon transferleri ya da artrodez uygulanır (Şekil 7). Pes kavus posteriorda ise sıklıkla ayağın plantigrad basması durumunda osteotomi yapılmaz. Kısalık varsa telafi edilir. 

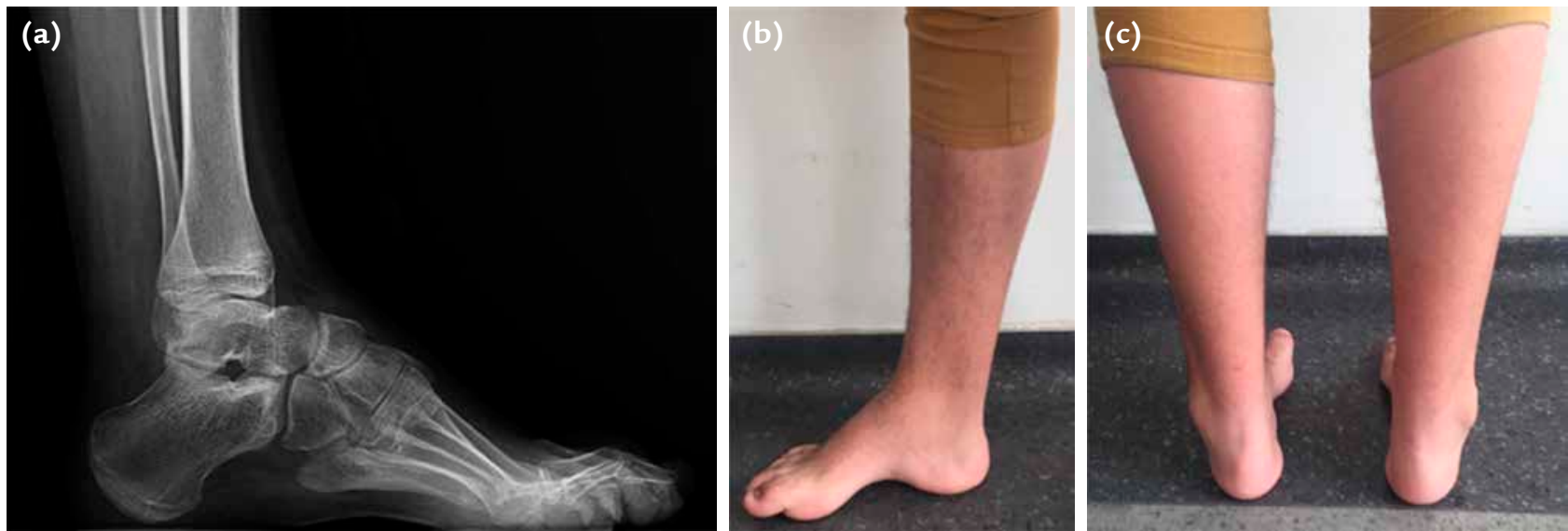

Şekil 7. a-c. Pes kalkaneovarus deformitesi bulunan, Charcot-Marie-Tooth hastası. Röntgenografide orta ayakta kavus deformitesi ve ayak bileğinde kalkaneus deformitesi görülmektedir (a). Klinik fotoğrafta arka ayakta varus, sagittal plan orta ayakta kavus deformitesi, ön ayakta birinci metatars başı düşüklüğü görülmektedir $(b, c)$.

\section{Ayak Bileği Osteoartriti ve Artrodiastazis}

Ayak bileği osteoartritinin tedavisinde eklem distraksiyonu literatürde kullanılan yöntemlerden biridir. Bu metodun, sık uygulanan ayak bileği eklem replasman cerrahisi ve artrodez prosedürleri arasında yer alması her zaman tartışmalı olmuştur. Bu tartışmaların odağında endikasyonlar yer almaktadır. Paley ve ark.'na göre bu metodun uygulanabilmesi için uyumlu bir eklem yüzeyi, ağrı, eklem hareketi ve orta-ciddi arası bir eklem artrozu olması yeterlidir. İzole artrozlu olgularda menteşesiz teknik günümüzde daha geniş endikasyonlar ile menteşeli olarak uygulanmaktadır. Fiksatöre ek olarak hastalara, osteofit rezeksiyonları, kontraktür gevşetmeleri, eklem reoryantasyon osteotomileri, subtalar ve tarsal tünel gevşetme prosedürleri yapılmaktadır. Menteşeli metot uygulandığında eklem hareket açıklığında artma beklenmemekte, mevcut açıklığın korunması yeterli görülmektedir. ${ }^{[12]}$

\section{AYAK BILLEĞiNi iLGILENDIREN ÖZEL DURUMLAR}

\section{Artrodez Sekelleri}

Ayak bileği artrodezi komplikasyonlarından malunion deformitesinin düzeltilmesinde koronal ve sagittal planda mekanik aksların tanımlanması önemlidir. Lateral görüntülemede en sık malunion ekinus deformitesidir. Bu deformitenin düzeltilmesinde ayağın yeniden posteriora alınması ve talus lateral çıkıntısından yere dik uzanan sagittal plan mekanik aksının, distal tibia orta hattından inen middiyafizer mekanik tibia aksından daha posteriorda tutulmasına dikkat edilmelidir. Frontal planda sıklıkla deformite malunion hattında ya da eski rezeksiyon sınırındadır. Düzeltme sıklıkla frontal planda yapılan osteotomi ile her iki planın düzeltilmesi şeklinde olur. Düzeltme ilizarov sirküler fiksatörü ile tedrici olarak yapılabildiği gibi, intramedüller çiviler ve uzun kilitleme vidaları ile de akut olarak yapılabilir. ${ }^{[13,14]}$

\section{Flat Top Talus Deformitesi}

Flat top talus deformitesi sıklıkla idiyopatik pes ekinovarus deformitesinin düzeltilmesi esnasında ezilen ve daha sonra deforme bir şekilde remodele olan talus kıkırdağı sebebi ile meydana gelir (Şekil 8). Ancak fibular hemimeli ya da meningomyelosel gibi konjenital hastalıklarda da karşımıza çıkabilir. Deformite sıklıkla kısıtlı bir sagittal plan hareket arkı olan ya da tamamen hareketsiz, sert ve ağrısız ayak bileği ile ilişkilidir. Tedavide amaç ayağın proksimale çekilmesidir ve büyüme tamamlandığında supramalleoler osteotomi ile yapılır. Vertikal makaslama kuvvetlerinin istenmediği yuvarlak kubbeli normal talus anatomisine karşın flat top talusta mümkün olduğunda translasyona izin vermeden ayak ekinusu düzeltilir. Hareket arkının korunmasının göz önünde bulundurulmadığı durumlarda "U"ya da "V"şeklinde osteotomiler ve sıklıkla tedrici düzeltmeler ile aynı deformite düzeltilir ve ayak plantigrad basan pozisyona getirilebilir. Son bir alternatif olarak deformitenin akut olarak düzeltilmesi ve triple/subtalar veya orta ayak füzyonu uygulanabilir (Şekil 8). 

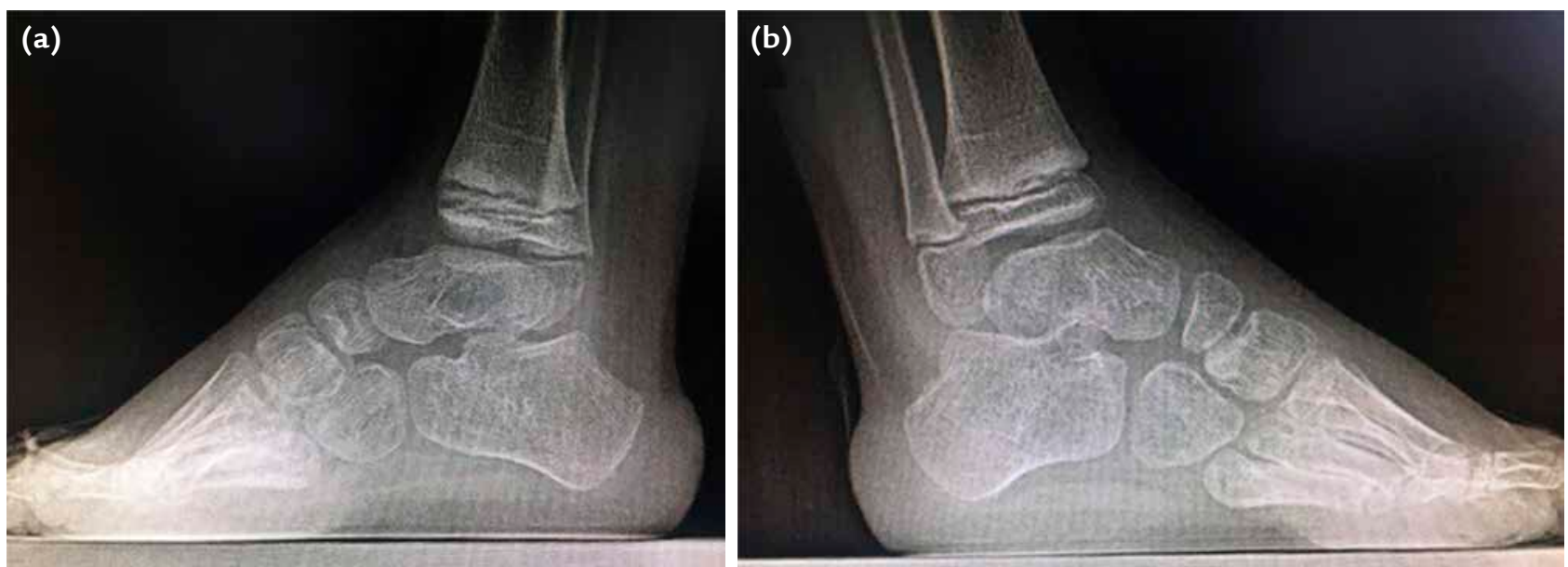

Şekil 8. a, b. Pes ekinovarus deformitesi tedavisi sonrasında tespit edilen flat top talus olgusu. Hastanın her iki ayağında (sağ, a; sol, b) bilateral uygulanan seri alçılama tedavisi sonrası flat top talus deformitesi gözlenmektedir.

\section{Fibular Patolojilere Bağlı Ayak Bileği Deformiteleri}

Fibulanın ayak bileği normal diziliminin sağlanmasında bir koruyucu görevi vardır. Ayak bileği hareketleri esnasında, hareketli bir eklem oluşturan fibula, kronik yük dağılımı çeşitliliklerinden etkilenir. Ayak bileği deformitelerine sebep olan fibular patolojiler aşağıdaki tabloda listelenmiştir.

\section{Ayak Bileği Deformitelerine Sebep Olan Fibular Patolojiler}

- Fibular hemimeli (statik deformite yaratır)

- Fibular hemimeli, Top-Soket Tipi Ayak Bileği (dinamik deformite yaratır)

- Yüksek fibular istasyon (Malhotra 1, 2, 3)

- Fibular malunion

- Fibular nonunion

- Fibula rezeksiyonu

- Konjenital tibia pseudoartrozu (Fibular Ps eşlik eden)

Top-Soket tipi ayak bileği morfolojisi sıklıkla fibular hemimelinin hafif tiplerinde görülür (Şekil 9a). Fibular hemimeliye bazı olgularda eşlik eden subtalar füzyon ya da fibulanın hipoplazisi tek başına bu patomorfolojiye eşlik edebilir, ancak sebebi olduğu düşünülmemektedir. Bu morfoloji sıklıkla ayak bileğinde olmaması gereken bir valgus momenti yaratarak tibialis posterior tendonuna zarar verir. Ayakta bir dinamik instabilite yaratır. Önceleri tedavi edilmesinin gerek olmadığı
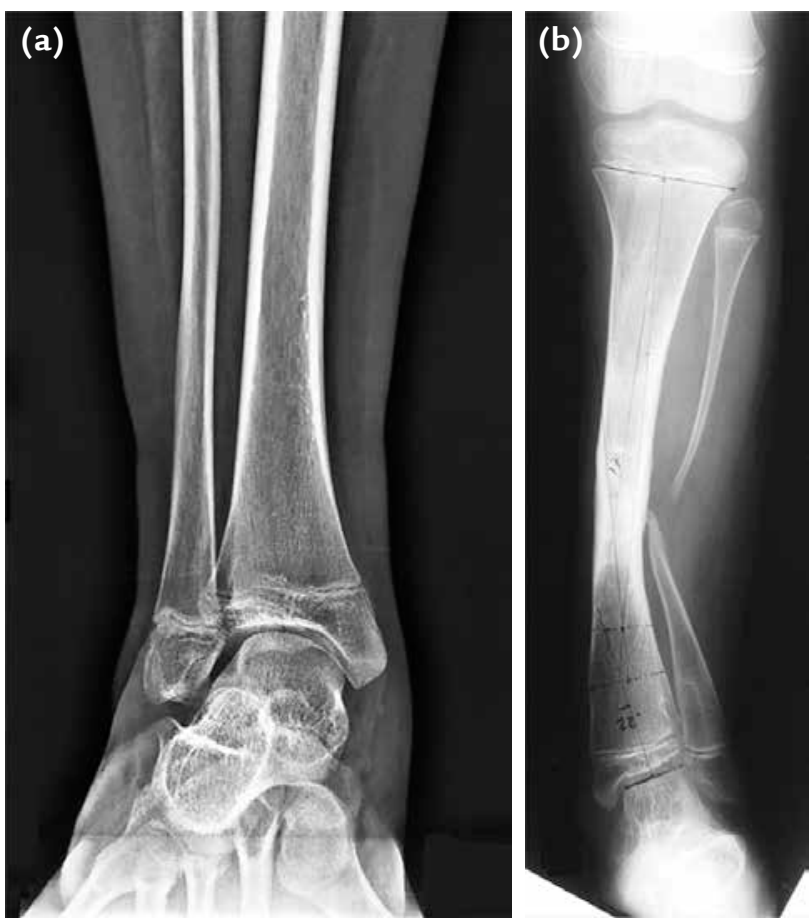

Şekil 9. a, b. Fibular patolojilerin etkilediği ayak bileklerine örnekler. Fibular hemimeli, Paley Tip 2, top-soket tipi ayak bileği (a). Konjenital tibia pseudoartrozu, başarılı bir kaynama sağlandıktan sonra uzun dönem takipte valgus deformitesi gelişimi (b). (Prof. Dr. Mehmet Kocaoğlu'nun arşivinden izin ile alınmıştır.)

düşünülen bu morfoloji, ilk olarak fibulanın izole olarak uzatılması sonraları ise supramalleoler osteotomi "Kural 2" düzeltmeleri ile tedavi edilmeye çalışılmıştır. Günümüzde ise bu tip ayak bileği için distal tibia 

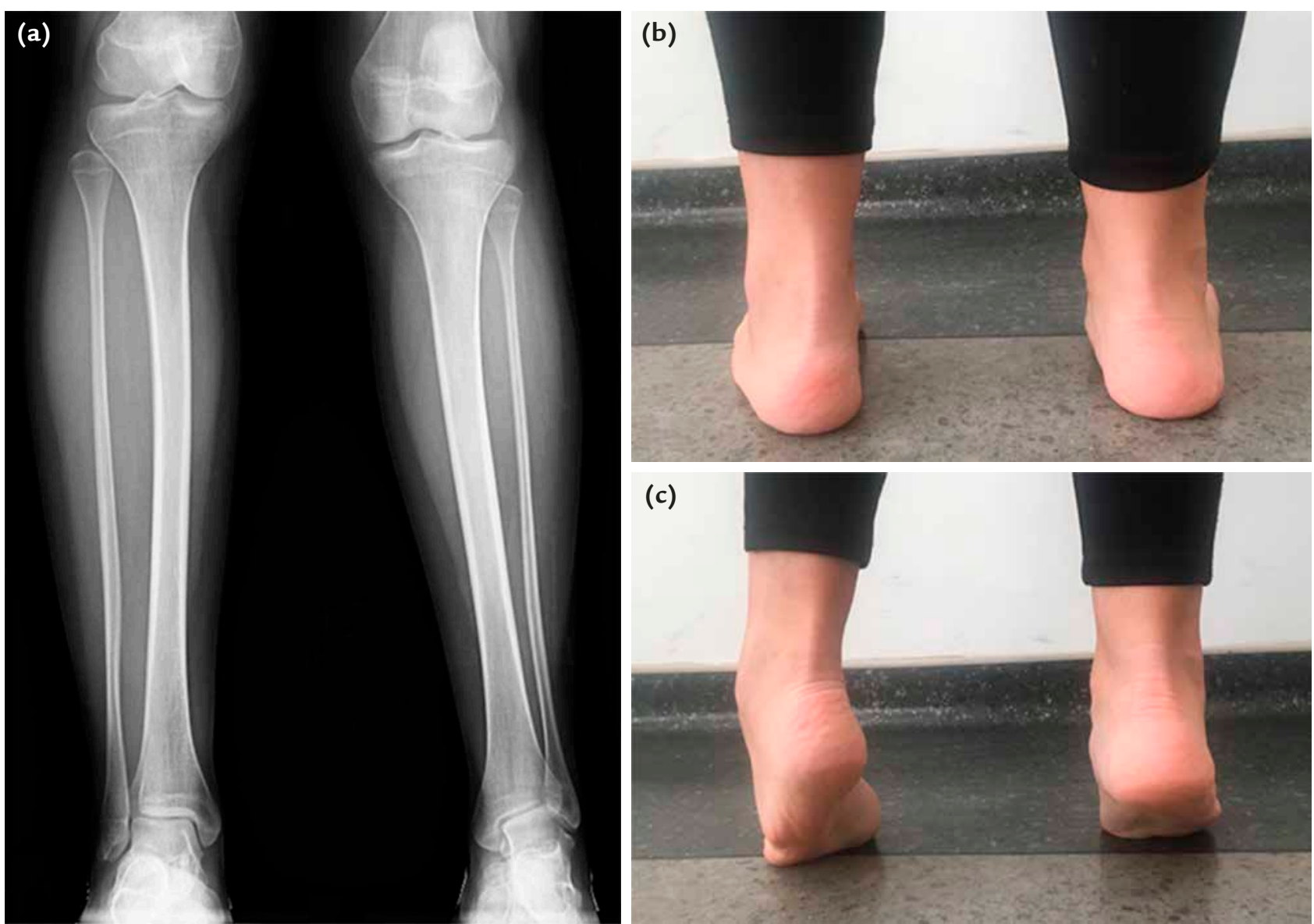

Şekil 10. a-c. Fibular patolojilerin etkilediği ayak bileklerine örnekler. Fibular istasyon kusuruna bağlı yüksek evre Malhotra fibula (a). Eski büyüme plağı kalıntılarından Evre 2 olduğu anlaşılıyor. Fibular istasyon kusuru uzun dönemde hastada ayak bileği maloryantasyonu yaratıyor. Eklem yüzeyine binen makaslama kuvvetleri artıyor. Hastanın yaşının genç olması sebebi ile ayak bileği kompansasyon mekanizmaları devreye giriyor ve klinikte deformite görünüm oluşturmuyor (b). Ancak hasta parmak ucunda yükseldiğinde subtalar kompansasyon mekanizması sebebi ile daima kontrakte olan kas kuvvetleri arka ayağı varusa getiriyor (c).

kısaltma osteotomileri ve sindezmoz bağ rekonstrüksiyonu ameliyatları popülerdir. ${ }^{[4]}$ Gerek fibulanın izole uzatılması, gerekse distal tibia kısaltma ve düzeltme ameliyatlarının sonuçları için uzun dönem ve yeterli kanıt düzeyinde bilgi bulunmamaktadır. ${ }^{[15]}$ Fibular hemimelinin diğer tiplerinde ise daha statik ayak bileği deformiteleri meydana gelir.

Konjenital tibia pseudoartrozu (KTP), anterolateral eğrilik, tibia fraktürleri, tibia psödoartrozları ve fibular psödoartozlar ile çeşitlilik gösteren bir hastalıktır. KTP'de yıllar içinde çeşitli tedavi yöntemleri denenmiş ancak çok yüksek başarı oranlarına ulaşılamamıştır. Son yıllarda biyolojik stimülasyon ile kombine edilen cerrahiler ile başarı oranları yükselse de uzun dönem sonuçlar henüz yeterli kanıt düzeyine ulaşmamıştır. [16] KTP uzun dönemde ayak bileğinde çok yüksek oranlarda valgus deformitesi ve geçirilen seri cerrahiler neticesinde sert ve deforme ayaklar ile seyretmektedir (Şekil 9b). Choi ve ark. tibia ve fibulanın distal sinostozunun hedeflendiği " 4 in 1 osteosentezi" metodu ile KTP tedavisinde fibular cerrahilerin önemini vurgulamış, Paley ise "X-union" adını verdiği tekniğe son yıllarda aynı şekilde sinostoz cerrahisi eklemiştir. Her iki yöntemde de uzun dönem sonuçlar yeterli kanıt düzeyine ulaşmamıştır. ${ }^{16,17]}$

Çocukluk çağında meydana gelen epifiz hasarları, ya da genetik bir takım hastalıklarda fibula olması gerekenden daha yüksek pozisyonda kalabilir. Bu durumu Malhotra, dört ayrı seviyede sınıflamıştır. ${ }^{[6]}$ Normal pozisyon olan 0 seviyesinin üzerindeki seviyelerde ayak bileği önce dinamik, sonra statik valgus deformitesi ile bozulur (Şekil 10). Aynı durum, fibulanın edinilmiş 

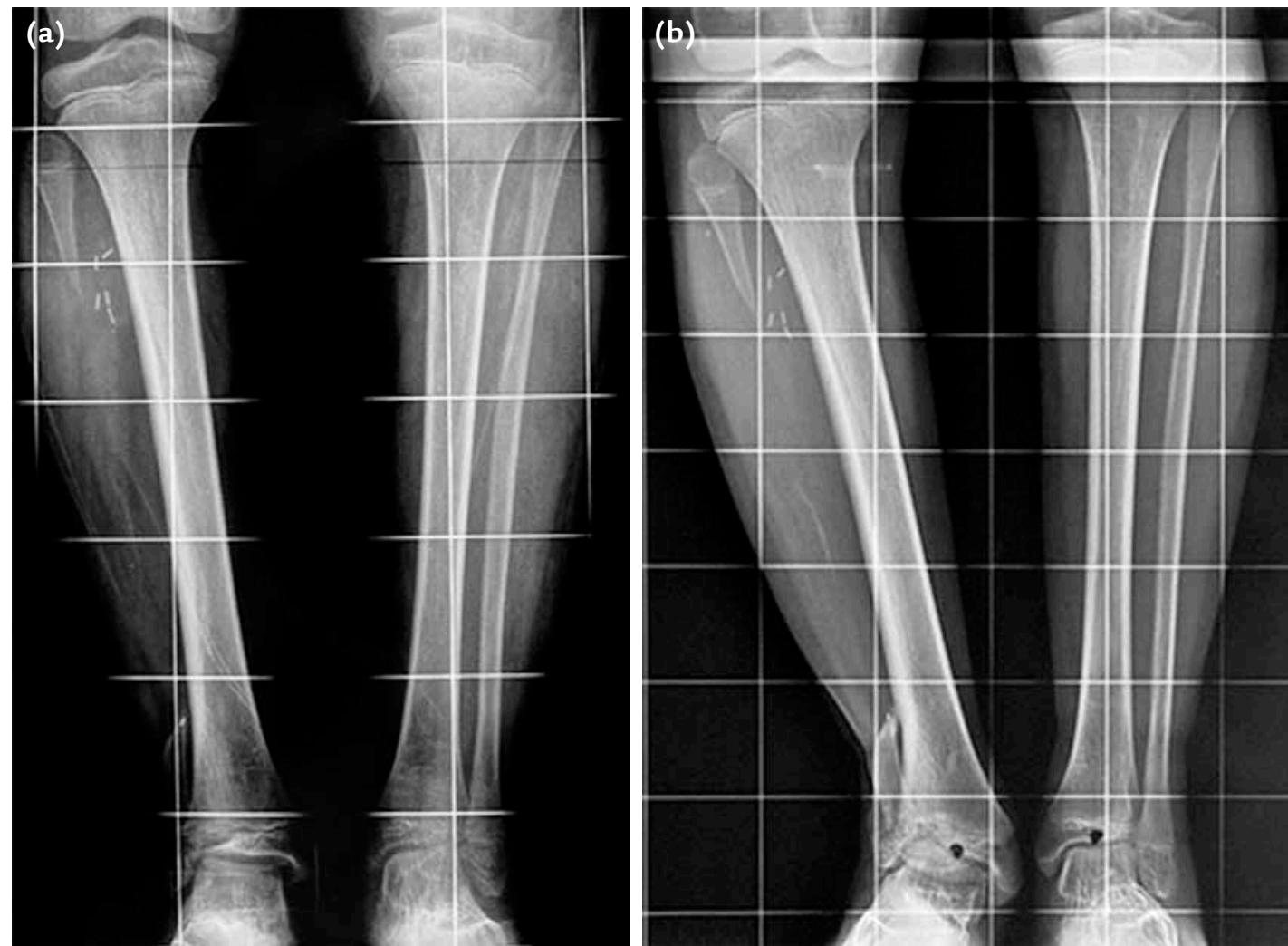

Şekil 11. a, b. Fibular patolojilerin etkilediği ayak bileklerine örnekler. Vaskülarize fibula transferi sebebi ile sağ kruris donör sahasının ve ayak bileğinin ayakta, yük verdirilerek çekilen anteroposterior grafisi (a). Aynı hastanın bir yıl sonraki kontrollerinde ayak bileği valgus deformitesinin ilerlemesi (b). (İstanbul Tıp Fakültesi, Ortopedi ve Travmatoloji Anabilim Dalı, ilizarov Arşivi.)

kaynamama, malunion ya da rezeksiyonuları sonucunda da görülür. Örneğin, damarlı fibula ameliyatı sonrasında dönör sahada valgus deformitesi, hastanın yaşı küçüldükçe daha sık görülür (Şekil 11).

\section{Pes Ekinovarus (PEV) Sekelleri, ihmal Edilmiş PEV ve Diğer Arka Ayak Lateralizasyon Deformiteleri}

PEV tedavisinin yapılması esnasında fazla düzeltme sonucunda arka ayak valgus deformitesi meydana gelir. Bu deformite aslında subtalar eklemde subluksasyona sebebiyet verecek bir kalkaneal translasyon ile birliktedir. Bu arka ayak problemleri kalkaneal medial translasyon osteotomisi ile ya da supramalleoler bir osteotomi ile düzeltilebilir. Ancak bu düzeltmeler yapılırken ön ayak ve bu bölge kaynaklı eşlik eden deformiteler de iyi analiz edilmelidir. Bu sayede gerektiği takdirde ön ayak derotasyon osteotomileri ve birinci sıra sagittal plan düzeltme osteotomileri ile ayak plantigrad basan hale gelebilir.

\section{Posterior Tibial Tendon Disfonksiyonu (PTTD)}

Tıpkı fazla düzeltilmiş PEV sekellerinde olduğu gibi supramalleoler osteotomi ya da kalkaneal medializasyon osteotomisi ile PTTD'nunun yarattığı fonksiyonel ve deforme kusur düzeltilebilir.

\section{Tamamen Sert Ayak}

Tamamen sert ayak kavus, ekinus, supinasyon ya da pronasyon deformiteleri ve bu deformitelerin bir ya da birden fazlasının el ile düzeltilemeyecek kadar sertleşmiş olduğu durumdur. Bu hareketsiz durumda ayağa manipülatif alçılar ya da ligament distraksiyonu fayda etmeyeceği için ayak ya da ayak bileği osteotomileri gerekir. Ayak deformiteleri tamamen sert ayaklarda supramalleoler osteotomiler ile fonksiyonel hale getirilebilir. Burada topuk temas noktası, birinci metatarsın temas noktası ve ayağın lateral sınııının oluşturduğu üç nokta aynı anda yüzeye temas edecek şekilde ayak bileği seviyesinden osteotomi ve düzeltme yapılır. Burada osteotomi "Kural 2" kullanılmalıdır. 


\section{Multipl Herediter Osteokondromatozis}

Multipl Herediter Osteokondromatozis (MHE) literatürde bir çok farklı şekilde adlandırılan, otozomal dominant kalıtılan ve musküloskeletal sistemde bir çok farklı lokalizasyonda osteokondrom oluşumu ile seyreden bir hastalıktır. İskelet büyümesi esnasında özellikle büyüme plaklarına çok yakın komşulukta seyreden osteokondrom formasyonları, dizilim kusuru, deformite ve özellikle eklemlerde maloryantasyon yaratır. MHE'de en sık diz ve ayak bileğinde valgus deformitesi görülür. Ayak bileği valgus deformitesi, osteokondrom oluşumundan bağımsız olarak, distal tibia epifizinin gelişimsel kusuru olarak görülebildiği gibi, sindezmoz hattında oluşan bir osteokondromun yarattığı maloryantasyon kusuru olarak da karşımıza çıkabilir. Tedavide ilk olarak "Büyüme Kontrolü” yöntemleri tercih edilmelidir. Yakın aralıklar ile takip edilen bu hastaların, osteokondrom oluşumu tespit edildiğinde, eklem hattında maloryantasyon oluşturmadan gerekli tümör rezeksiyonları yapılmalı, eklem hattının büyüm plağının parsiyel tespitleri ile oryantasyon kontrol altında tutulmalıdır. Büyüme potansiyelinin olmadığı ayak bileklerinde, düzeltici osteotomiler yapılmalıdır. ${ }^{[18-21]}$

\section{Epifiz Hasarları ve Parsiyel Büyüme Defektleri}

Bu tip hasarlar eğer eklemin \%25'inden fazlasını ilgilendirmiyorsa epifizer distraksiyon ile düzeltilebilir. Ancak tedavi bitiminde büyüme potansiyeli tamamen kaybedilmiş bir fiz hattı olur. Fiz kusuru sıklıkla diz bölgesinde intraartiküler bir deformite meydana getirir. Ancak ayak bileğinde de fiz kusuru sebebi ile maloryantasyon meydana gelebilir. Tedavi algoritması hastanın yaşı, büyüme potansiyeli ve fibulanın durumuna göre yapilır.

\section{KAYNAKLAR}

1. Lamm BM, Paley D. Deformity correction planning for hindfoot, ankle, and lower limb. Clin Podiatri Med Surg 2004;21(3):305-26. Crossref

2. Paley D. Ankle and Foot Considerations. In: Principles of Deformity Correction. Berlin, Heidelberg: Springer; 2002.

3. Çakmak M, Civan M. Ankle Deformities. In: Çakmak M, Şen C, Eralp L, Balci H, Civan M, editors. Basic Techniques for Extremity Reconstruction Switzerland: Springer; 2018. pp.413-40.

4. Paley D. Surgical reconstruction for fibular hemimelia. J Child Orthop 2016;10(6):557-83. Crossref

5. Shapiro F, Simon S, Glimcher MJ. Hereditary multiple exostoses. Anthropometric, roentgenographic, and clinical aspects. J Bone Joint Surg Am 1979;61(6):815-24. Crossref
6. Malhotra D, Puri R, Owen R. Valgus deformity of the ankle in children with spina bifida aperta. J Bone Joint Surg $\mathrm{Br}$ 1984;66-B(3):381-5. Crossref

7. Uysal M. Osteotomy Rules and Types. In: Çakmak M, Şen C, Eralp L, Balci H, Civan M, editors. Basic Techniques for Extremity Reconstruction Switzerland: Springer; 2018. pp.339-50.

8. Şen C, Akgül T. Translation and Angulation-Translation Deformities. In: Çakmak M, Şen C, Eralp L, Balci H, Civan $\mathrm{M}$, editors. Basic Techniques for Extremity Reconstruction Switzerland: Springer; 2018. pp.309-26.

9. Paley D. Sagittal Plane Deformities. In: Principles of Deformity Correction. Berlin, Heidelberg: Springer; 2002.

10. Herzenberg JE, Lamm BM, Corwin C, Sekel J. Isolated recession of the gastrocnemius muscle: the Baumann procedure. Foot Ankle Int 2007;28(11):1154-9. Crossref

11. Lamm BM, Paley D, Herzenberg JE. Gastrocnemius soleus recession: a simpler, more limited approach. J Am Podiatri Med Assoc 2005;95(1):18-25. Crossref

12. Paley D, Lamm BM, Purohit RM, Specht SC. Distraction arthroplasty of the ankle -how far can you stretch the indications? Foot Ankle Clin 2008;13(3):471-84. Crossref

13. Paley D, Lamm BM, Katsenis D, Bhave A, Herzenberg JE. Treatment of malunion and nonunion at the site of an ankle fusion with the Ilizarov apparatus. J Bone Joint Surg Am 2006;88(1):119-34. Crossref

14. Barg A, Saltzman CL. Joint-preserving procedures in patients with varus deformity: Role of supramalleolar osteotomies. Foot Ankle Clin 2019;24(2):239-64. Crossref

15. Chu A, Ong C, Henderson ER, Van Bosse HJ, Feldman DS. Distraction osteogenesis of the fibula to correct ankle valgus in multiple hereditary exostoses. Bull Hosp Jt Dis 2016;74(4):249-53.

16. Paley D. Congenital pseudarthrosis of the tibia: Combined pharmacologic and surgical treatment using Biphosphonate intravenous infusion and bone morphogenic protein with periosteal and cancellous autogenous bone grafting, tibio-fibular cross union, intramedullary rodding and external fixation. Bone Grafting: InTech; 2012. pp.91-106. Crossref

17. Choi IH, Lee SJ, Moon HJ, et al. "4-in-1 Osteosynthesis" for Atrophic-type Congenital Pseudarthrosis of the Tibia. J Pediatr Orthop 2011;31(6):697-704.

18. Chin KR, Kharrazi FD, Miller BS, Mankin HJ, Gebhardt MC. Osteochondromas of the distal aspect of the tibia or fibula: Natural history and treatment osteochondromas of the distal aspect of the tibia or fibula. J Bone Joint Surg Am 2008:82(9):1269-78. Crossref

19. Lee DY, Kim J II, Song MH, Choi ES, Park MS, Yoo WJ, Chung $\mathrm{CY}$, Choi IH, Cho TJ. Fibular lengthening for the management of translational talus instability in Hereditary multiple exostoses patients. J Pediatr Orthop 2014;34(7):726-32. Crossref

20. Dias LS. Valgus deformity of the ankle joint: pathogenesis of fibular shortening. J Pediatr Orthop 1985;5(2):176-80. Crossref

21. Dias LS. Ankle valgus in children with myelomeningocele. Dev Med Child Neurol 1978;20(5):627-33. Crossref 